2. Hadfield J, Megill C, Bell SM, Huddleston J, Potter B, Callender C, et al. Nextstrain: real-time tracking of pathogen evolution. Bioinformatics. 2018;34:4121-3. https:/ / doi.org/10.1093/bioinformatics/bty407

3. Sagulenko P, Puller V, Neher RA. TreeTime: maximumlikelihood phylodynamic analysis. Virus Evol. 2018;4:vex042. https://doi.org/10.1093/ve/vex042

4. West AP, Wertheim JO, Wang JC, Vasylyeva TI, Havens JL, Chowdhury MA, et al. Detection and characterization of the SARS-CoV-2 lineage B.1.526 in New York. Nat Comm. 2021;12:4886. https://doi/org/10.1038/s41467-021-25168-4

5. World Organisation for Animal Health. COVID-19 [cited 2021 May 19]. https:/ / www.oie.int/en/what-we-offer/ emergency-and-resilience/covid-19

6. US Department of Agriculture Animal and Plant Health Inspection Service. Cases of SARS-CoV-2 in animals in the United States [cited 2021 May 19]. https:/ / www.aphis.usda. gov/aphis/dashboards/tableau/sars-dashboard

7. Delahay RJ, de la Fuente J, Smith GC, Sharun K, Snary EL, Flores Girón L, et al. Assessing the risks of SARS-CoV-2 in wildlife. One Health Outlook. 2021;3:7. https://doi. org/10.1186/s42522-021-00039-6

8. Hamer SA, Ghai RR, Zecca IB, Auckland LD, Roundy CM, Davila E, et al. SARS-CoV-2 B.1.1.7 variant of concern detected in a pet dog and cat after exposure to a person with COVID-19, USA. Transbound Emerg Dis. 2021 May 12 [Epub ahead of print] https:// doi.org/10.1111/tbed.14122

Address for correspondence: Diego G. Diel, Animal Health Diagnostic Center, Cornell University, 240 Farrier Rd, Ithaca, NY 14853, USA; email: dgdiel@cornell.edu

\section{Postmortem Stability of SARS-CoV-2 in Mouse Lung Tissue}

\author{
Sophie A. Valkenburg, Samuel M.S. Cheng, \\ Asmaa Hachim, Malik Peiris, John Nicholls \\ Author affiliations: The University of Hong Kong, Hong Kong, China
}

DOI: https://doi.org/10.3201/eid2712.211621

The infectivity of severe acute respiratory syndrome coronavirus 2 in deceased persons and organisms remains unclear. We studied transgenic K18 hACE2 mice to determine the kinetics of virus infectivity after host death. Five days after death, virus infectivity in the lung declined by $>96 \%$ and RNA copies declined by $48.2 \%$.
The safe handling and disposal of bodies of persons who have died of coronavirus disease (COVID-19) is vital for infection control. Although cremation or burial practices are mainly dictated by religious and societal customs, deaths associated with contagious illness warrant appropriate precautions. Severe acute respiratory syndrome coronavirus 2 (SARS-CoV-2), the causative agent of COVID-19, is rapidly inactivated $\left(>2 \log _{10}\right)$ within hours on nonporous surfaces (1). In addition, several studies have detected viral RNA by reverse transcription PCR (RT-PCR) of nasopharyngeal and pharyngeal mucosal swab specimens, skin swab specimens, and tissue samples collected during autopsies at different times after death (2-5). Furthermore, infectious virus was isolated in 2 of 4 cases at 4-17 days postmortem; however, this study did not quantify virus titers to determine the loss of virus infectivity (6). A separate study found that infectious virus was undetectable after exhumation at 3-4 months postmortem (7). Overall, RNA detection by RT-PCR might not directly correlate with virus infectivity or duration of symptomatic disease.

Transgenic K18-hACE2 mice provide a surrogate model to study the kinetics of SARS-CoV-2 viral replication during infection (8) and after host death. In humans and K18-hACE2 mice, little evidence exists for extrapulmonary dissemination of SARS-CoV-2, except for neurotropism in younger mice, a finding that has not been demonstrated reliably in humans. We investigated the temporal decay of infectious SARSCoV-2 in postmortem tissues of infected K18-hACE2 mice. All experimental procedures were conducted in accordance with the standards and approved by the Committee on the Use of Live Animals in Teaching and Research (approval no. 5511-20) at The University of Hong Kong (Hong Kong, China).

We infected twelve 14-20-week-old mice with $1 \times$ $10^{4} 50 \%$ tissue culture infectious dose $\left(\mathrm{TCID}_{50}\right) / 25 \mu \mathrm{L}$ SARS-CoV-2 by the intranasal route. Five days later, after the mice had lost 18.8\% (SD 7.77\%) of their body weight, we euthanized them by ketamine/xylazil anesthesia. We wrapped each carcass in a sealable plastic bag, similar to the storage of human corpses, and stored them intact at $4^{\circ} \mathrm{C}$, which is standard mortuary temperature. On days $0,1,5$, and 14 after death, we dissected 3 carcasses and tested the lung tissue for coronavirus nucleoprotein $(\mathrm{N})$ by histologic and immunohistochemistry assays (9) (Appendix Figure, panels A-H, https://wwwnc.cdc.gov/EID/ article/27/12/21-1612-App1.pdf). We quantified infectious virus by culture (Figure, panel A) and viral RNA by RT-PCR (Figure, panel B) (Appendix). 


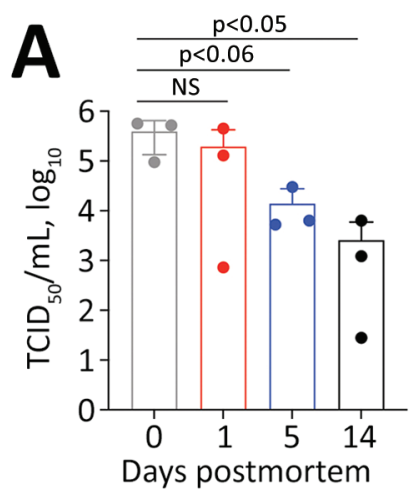

B
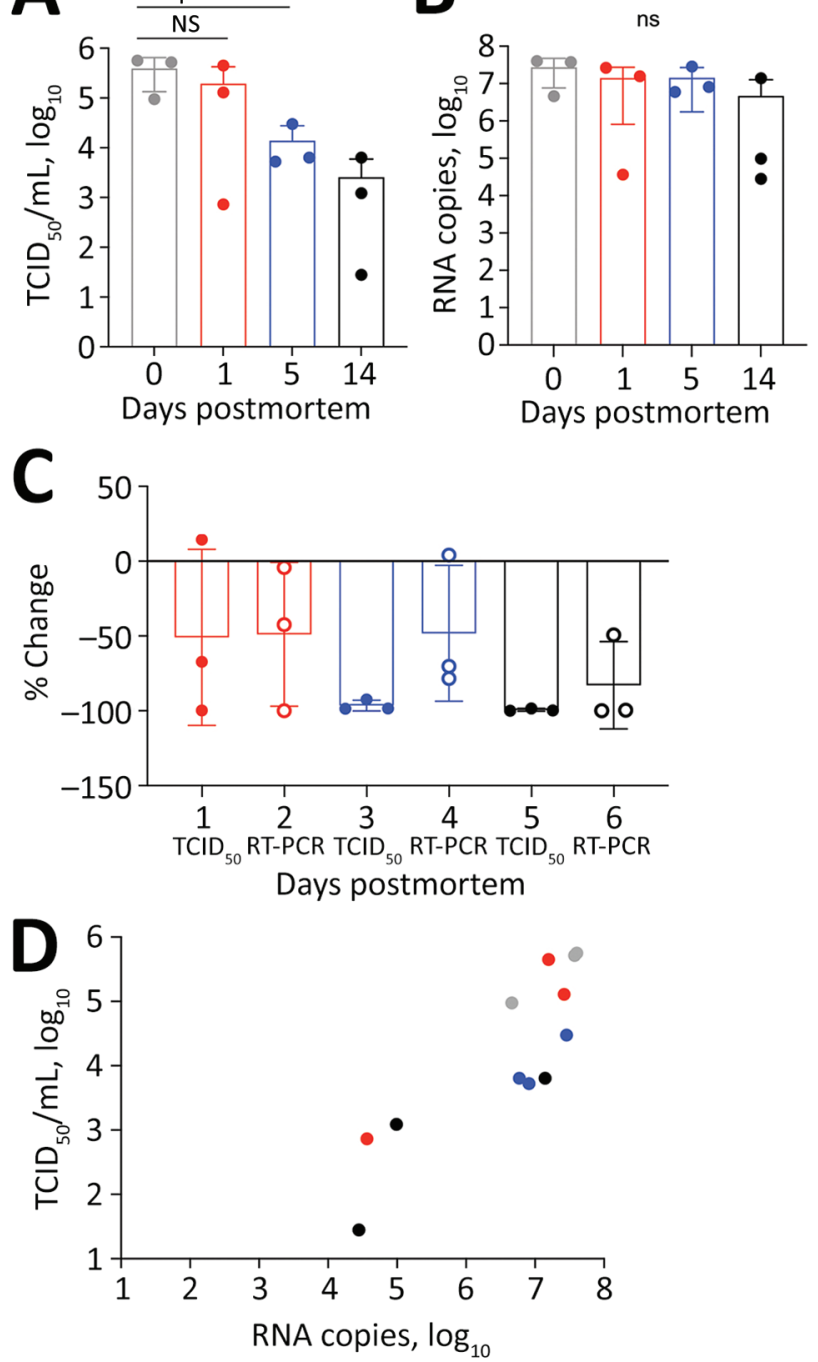

Figure. Postmortem stability of severe acute respiratory syndrome coronavirus 2 in mouse lung tissue. A) Infectious virus measured by $\mathrm{TCID}_{50}$ of VeroE6 cells. B) Viral RNA measured by copies of $\mathrm{N}$ gene detected by RT-PCR. C) Percentage change compared with day 0 . D) Correlation between infectious virus and viral RNA $\mathrm{R}^{2}=0.51 ; F=0.005$ by analysis of variance. NS, not significant; RT-PCR, reverse transcription PCR; $\mathrm{TCID}_{50}, 50 \%$ tissue culture infectious dose.
Viral decay, measured using $\mathrm{TCID}_{50}$ for infectious virus and RNA copies of the $\mathrm{N}$ gene detected by RT-PCR, occurred over a 14-day period (Table). At day 1 we observed a $50 \%$ reduction of infectious virus and $48.8 \%$ loss of viral RNA (Figure, panels A, B). By day 5, levels of infectious virus had fallen by $96.5 \%$, whereas viral RNA remained at $48.2 \%$ compared with day 0 (Figure, panels C, D). At day 14 only $0.7 \%$ of the initial infectious virus and $17 \%$ of viral RNA remained. Plenzig et al. (7) detected viral RNA in 2 exhumed corpses at 3 months postmortem, despite an absence of infectious virus. We used hematoxylin and eosin staining to detect viral nucleoprotein in lung tissue. We observed persistent antigen staining until day 5; by day 14, only 1 of 3 samples had detectable staining (Appendix Figure).

We euthanized the mice 5 days after infection, when the lungs had a high viral load. However, COVID-19 deaths usually occur during later stages of disease, by which time infectious viral load has decreased from the peak usually seen early during the symptomatic phase of the illness (10). We detected virus antigen in the lungs of all mice at 5 days postmortem; infectious virus had declined by $96.48 \%$, but viral RNA declined by only $48.21 \%$. Our results shows that infectious virus declines earlier than viral RNA or antigen in postmortem tissues.

These findings have implications for the safe handling of deceased COVID-19 patients. Infectious virus can persist on inanimate surfaces for up to 14 days at lower temperatures $\left(<4^{\circ} \mathrm{C}\right)$, but rapidly decays in postmortem tissue samples. We observed a $96.5 \%$ decrease in infectious virus by day 5 and a $99.3 \%$ decrease by day 14 . Most published postmortem studies in humans have reported viral load at the time of death using cycle threshold values rather than $\mathrm{N}$ gene copies as we have done; results range from 17-36 for cycle threshold values and 0-5.49 $\log _{10}$ for $\mathrm{N}$ gene copies (11). Therefore, the maximum potential risk of transmission from an infected

Table. Postmortem viral loads in K18-hACE2 mice lung tissue after 5 days of infection with severe acute respiratory syndrome coronavirus $2^{*}$

\begin{tabular}{|c|c|c|c|c|c|c|c|}
\hline Day & $\begin{array}{c}\mathrm{N} \text { gene copies, } \\
\log _{10}\end{array}$ & $\begin{array}{c}\% \text { Reduction of } \mathrm{N} \\
\text { gene copies }\end{array}$ & $\begin{array}{c}\mathrm{TCID}_{50} / \mathrm{mL} \\
\log _{10} \\
\end{array}$ & $\begin{array}{c}\% \text { Reduction of } \\
\text { TCID }_{50} / \mathrm{mL} \dagger\end{array}$ & $\begin{array}{c}\text { Lung } \\
\text { inflammation } \\
\text { score } \neq\end{array}$ & $\begin{array}{c}\text { SARS-CoV-2 N } \\
\text { protein } \\
\text { antigen score§ }\end{array}$ & $\begin{array}{l}\text { Positive for } \\
\text { SARS N } \\
\text { proteinף }\end{array}$ \\
\hline 0 & $7.28+0.53$ & NA & $5.48+0.44$ & NA & $9.33+1.53$ & $3.66+1.15$ & $3(100.0)$ \\
\hline 1 & $6.39+1.59$ & $-48.85+48.14$ & $4.54 \pm 1.48$ & $-50.88+58.82$ & $7 \pm 2$ & $2.66+2.31$ & $2(66.6)$ \\
\hline $5 \#$ & $7.05 \pm 0.36$ & $-48.21 \mp 45.43$ & $4.00 \pm 0.41$ & $-96.48+3.54$ & $5.33+4.61$ & $4+1.4$ & $2(100.0)$ \\
\hline 14 & $5.53+1.43$ & $-82.95+29.13$ & $2.78+1.21$ & $-99.35+0.86$ & $10.33+1.53$ & $1.66+2.88$ & $1(33.3)$ \\
\hline
\end{tabular}

*Values are mean \pm SD, except as indicated. NA, not applicable; $\bar{T}$ CID $50,50 \%$ tissue culture infectious dose.

tCompared with day 0 .

¥Scale of $0-16$, in which 16 represents most severe inflammation.

$\S$ Scale of $0-5$, in which 5 represents highest amount of antigen.

TValues are no. (\%).

\#Days 0,1 , and 14 values reflect 3 mice. Day 5 values reflect 2 mice for histology and 3 mice for TCID 50 and reverse transcription PCR. 
corpse is during the first 24 hours after death. By day 5 , the amount of infectious virus has decreased by $96.48 \%$. If proper biosafety precautions and personal protective equipment are used to handle the corpse during autopsy or preparation for burial or cremation, we believe that the burial or cremation process is unlikely to spread disease.

This study was partly supported by the Health and Medical Research Fund (grant no. HMRF COVID-190115 to M.P. and S.A.V.), and Commissioned Research on Control of Infectious Diseases (phase III and IV) from the Health and Medical Research Fund (M.P.).

\section{About the Author}

Dr. Valkenburg is a viral immunologist at the HKUPasteur Research Pole, University of Hong Kong, Hong Kong, China. Her research interests include immune correlates for influenza and severe acute respiratory syndrome coronavirus 2 .

\section{References}

1. Chin AWH, Chu JTS, Perera MRA, Hui KPY, Yen HL, Chan MCW, et al. Stability of SARS-CoV-2 in different environmental conditions. Lancet Microbe. 2020;1:e10. https:/ / doi.org/10.1016/S2666-5247(20)30003-3

2. Heinrich F, Meißner K, Langenwalder F, Püschel K, Nörz D, Hoffmann A, et al. Postmortem stability of SARS-CoV-2 in nasopharyngeal mucosa. Emerg Infect Dis. 2021;27:329-331. https:/ / doi.org/10.3201/eid2701.203112

3. Skok K, Stelzl E, Trauner M, Kessler HH, Lax SF. Post-mortem viral dynamics and tropism in COVID-19 patients in correlation with organ damage. Virchows Arch. 2021;478:343-53. https://doi.org/10.1007/ s00428-020-02903-8

4. Sablone S, Solarino B, Ferorelli D, Benevento M, Chironna M, Loconsole D, et al. Post-mortem persistence of SARS-CoV-2: a preliminary study. Forensic Sci Med Pathol. 2021;17: 403-410. https://doi.org/10.1007/s12024-021-00375-Z

5. Schröder AS, Edler C, Ondruschka B, Püschel K, Schädler J, Heinemann A, et al. The handling of SARS-CoV-2 associated deaths - infectivity of the body. Forensic Sci Med Pathol. 2021;17:411-418. https://doi.org/10.1007/ s12024-021-00379-9

6. Plenzig S, Bojkova D, Held H, Berger A, Holz F, Cinatl J, et al. Infectivity of deceased COVID-19 patients. Int J Legal Med. 2021;135:2055-60. https:/ / doi.org/10.1007/ s00414-021-02546-7

7. Plenzig S, Holz F, Bojkova D, Kettner M, Cinatl J, Verhoff MA, et al. Detection and infectivity of SARS-CoV-2 in exhumated corpses. Int J Legal Med. 2021 Jul 24 [Epub ahead of print]. https:// doi.org/10.1007/s00414-021-02670-4

8. Zheng J, Wong LR, Li K, Verma AK, Ortiz ME, Wohlford-Lenane C, et al. COVID-19 treatments and pathogenesis including anosmia in K18-hACE2 mice. Nature. 2021;589:603-7. https:/ / doi.org/10.1038/s41586-020-2943-Z

9. Perera RAPM, Tso E, Tsang OTY, Tsang DNC, Fung K, Leung YWY, et al. SARS-CoV-2 virus culture and subgenomic RNA for respiratory specimens from patients with mild coronavirus disease. Emerg Infect Dis. 2020;26:2701-4. https://doi.org/10.3201/eid2611.203219

10. Zou L, Ruan F, Huang M, Liang L, Huang H, Hong Z, et al. SARS-CoV-2 viral load in upper respiratory specimens of infected patients. N Engl J Med. 2020;382:1177-9. https://doi.org/10.1056/NEJMc2001737

11. Nienhold R, Ciani Y, Koelzer VH, Tzankov A, Haslbauer JD, Menter T, et al. Two distinct immunopathological profiles in autopsy lungs of COVID-19. Nat Commun. 2020;11:5086. https://doi.org/10.1038/s41467-020-18854-2

Address for correspondence: John Nicholls, Block T, Queen Mary Hospital, The University of Hong Kong, Pokfulam, Hong Kong, China; email: nicholls@pathology.hku.hk

\section{Guillain-Barré Syndrome Associated with COVID-19 Vaccination}

\author{
Shih-Chieh Shao, ${ }^{1}$ Chien-Ho Wang, ${ }^{1}$ Kai-Cheng \\ Chang, Ming-Jui Hung, Hui-Yu Chen, Shu-Chen Liao \\ Author affiliations: Keelung Chang Gung Memorial Hospital, \\ Keelung, Taiwan (S.-C. Shao, C.-H. Wang, M.-J. Hung, \\ S.-C. Liao); National Cheng Kung University College of Medicine, \\ Tainan, Taiwan (S.-C. Shao, K-C, Chang); Linkou Chang Gung \\ Memorial Hospital, Taoyuan, Taiwan (K.-C. Chang, H.-Y. Chen); \\ Chang Gung University College of Medicine, Taoyuan \\ (M.-J. Hung, S.-C. Liao)
}

DOI: https://doi.org/10.3201/eid2712.211634

We conducted a multi-institutional study in Taiwan and a systematic review of the literature for reports of Guillain-Barré syndrome after coronavirus disease vaccination. This condition, mostly the classic form and the acute inflammatory demyelinating polyneuropathy subtype, has been reported in 39 cases and has occurred within 2 weeks of vaccine administration.

uillain-Barré syndrome (GBS), an immune-
mediated polyradiculoneuropathy with a $\approx 5 \%$
mortality rate, has an incidence worldwide of $0.81-$
1.91 cases/100,000 person-years (1). GBS has been

${ }^{1}$ These authors contributed equally to this article. 